\title{
Acute hemodynamic response to single oral doses of BAY 60-4552, a soluble guanylate cyclase stimulator, in patients with biventricular heart failure \\ Veselin Mitrovic*1, B Swidnicki ${ }^{1}$, Ardeschir Ghofrani ${ }^{2}$, Wolfgang Mück ${ }^{3}$, Nina Kirschbaum ${ }^{4}$, Joachim Mittendorf ${ }^{5}$, Johannes-Peter Stasch6, Georg Wensing 3 , Reiner Frey ${ }^{3}$ and Silvia Lentini*3
} \author{
Schering Pharma AG, Pharma Research Centre, 42096 Wuppertal, Germany \\ Email: Veselin Mitrovic* - v.mitrovic@kerckhoff-klinik.de \\ * Corresponding authors \\ from 4th International Conference of cGMP Generators, Effectors and Therapeutic Implications \\ Regensburg, Germany. 19-21 June 2009 \\ Published: II August 2009 \\ BMC Pharmacology 2009, 9(Suppl I):P5I doi:I0.II86/I47|-2210-9-SI-P5 I
}

Address: ${ }^{1}$ Kerckhoff Heart Center, Department of Cardiology, 61231 Bad Nauheim, Germany, ${ }^{2}$ Department of Internal Medicine, Medical Clinic II/V, University Hospital Giessen and Marburg GmbH, Klinikstrasse 36, 35392 Giessen, Germany, ${ }^{3}$ Clinical Pharmacology, 42096 Wuppertal, Germany, ${ }^{4}$ Global Biostatistics, 42096 Wuppertal, Germany, ${ }^{5}$ Medicinal Chemistry, 42096 Wuppertal, Germany and ${ }^{6}$ Cardiology Research, Bayer

This abstract is available from: http://www.biomedcentral.com/I47I-22I0/9/SI/P5 I

(c) 2009 Mitrovic et al; licensee BioMed Central Ltd.

\section{Background}

BAY $60-4552$ is a direct soluble guanylate cyclase (sGC) stimulator that acts independently of nitric oxide (NO). In preclinical studies BAY 60-4552 exhibited potent vasorelaxing properties and end-organ protective effects. Secondary pulmonary hypertension is a determinant of morbidity and mortality in patients with biventricular heart failure (bivHF). Weassumed that BAY 60-4552 would improve cardiopulmonary hemodynamics by restoring functionality of the $\mathrm{NO} / \mathrm{sGC} / \mathrm{cGMP}$ pathway and be well tolerated in patients with bivHF.

\section{Methods}

This study evaluated safety, tolerability and invasive hemodynamics of $1,2.5,5,7.5$ and $10 \mathrm{mg}$ oral BAY 604552 in patients with bivHF (LVEF $\leq 45 \%$, mean pulmonary artery pressure $(\mathrm{mPAP}) \geq 25 \mathrm{mmHg}$, pulmonary capillary wedge pressure $[\mathrm{PCWP}] \geq 18 \mathrm{mmHg}$ ).

\section{Results}

31 male and 11 female patients $(65 \pm 11$ years; BMI 27.4 \pm 4.4 ) were included. Mean hemodynamic parameters at baseline were PCWP: $23.9 \pm 4.5 \mathrm{mmHg}$; right atrial pres- sure (RAP): $10.6 \pm 4.3 \mathrm{mmHg}$; mPAP: $35.7 \pm 8 \mathrm{mmHg}$; systolic blood pressure (SBP): $119.2 \pm 17.4 \mathrm{mmHg}$; systemic vascular resistance (SVR): $1721 \pm 534$ dyn $\bullet \mathrm{s}^{\bullet} \mathrm{cm}^{-5}$; heart rate $(\mathrm{HR}): 70.6 \pm 11.2 \mathrm{bpm}$; and cardiac index $(\mathrm{CI})$ : $1.99 \pm 0.48 \mathrm{~L} / \mathrm{min} / \mathrm{m}^{2}$. Table 1 summarizes peak changes in invasive hemodynamics aftersingle dosesof 2.5, 7.5 and $10 \mathrm{mg}$. No relevant HR increase was observed. BAY 604552 was safe and well tolerated with mild adverse events (asymptomatic hypotension, $\mathrm{n}=1$; transient facial flushing, $\mathrm{n}=5$; mild headache, $\mathrm{n}=4$ ). Pharmakokinetic parameters were linear and mean elimination half-life ranged between $14-20 \mathrm{~h}$.

\section{Conclusion}

In patients with bivHF, oral administration of BAY 604552 was well tolerated and mediated a potent vasodilation. Biventricular pre- and afterload were improved, which resulted in a significant increase in cardiac index. These first clinical results with an oral sGC stimulator in patients with bivHF demonstrate the potential of this new therapeutic principle. 
Table I: Changes in hemodynamic parameters

\begin{tabular}{llll}
\hline & $2.5 \mathrm{mg}(\mathrm{n}=7)$ & $7.5 \mathrm{mg}(\mathrm{n}=12)$ & $10 \mathrm{mg}(\mathrm{n}=12)$ \\
\hline PCWP [mmHg] & $-7.3 \pm 2.8[-28 \pm 10 \%]$ & $-8.4 \pm 3.1[-36 \pm 13 \%]$ & $-9.3 \pm 2.5[-43 \pm 11 \%]$ \\
$\mathrm{MPAP}[\mathrm{mmHg}]$ & $-8.9 \pm 6.1[-22 \pm 12 \%]$ & $-8.0 \pm 3.3[-24 \pm 9 \%]$ & $-7.3 \pm 3.3[-23 \pm 8 \%]$ \\
RAP [mmHg] & $-3.1 \pm 3.5[-26 \pm 29 \%]$ & $-4.3 \pm 1.9[-40 \pm 15 \%]$ & $-4.0 \pm 2.3[-39 \pm 15 \%]$ \\
SVR [dyn•s॰cm -5$]$ & $-378 \pm 550[-15 \pm 21 \%]$ & $-523 \pm 293[-33 \pm 15 \%]$ & $-546 \pm 267[-31 \pm 12 \%]$ \\
$\mathrm{Cl}\left[\mathrm{L} / \mathrm{min} / \mathrm{m}^{2}\right]$ & $+0.3 \pm 0.3[+17 \pm 22 \%]$ & $+0.6 \pm 0.4[+31 \pm 22 \%]$ & $+0.7 \pm 0.5[+33 \pm 25 \%]$ \\
\hline
\end{tabular}

Changes from baseline (absolute and [relative] mean \pm SD) of invasive hemodynamics after oral administration of 2.5, 7.5 and 10 mg BAY60-4552, $\mathrm{P}$ $<0.05$ (for each change from baseline).

Publish with Bio Med Central and every scientist can read your work free of charge

"BioMed Central will be the most significant development for disseminating the results of biomedical research in our lifetime. " Sir Paul Nurse, Cancer Research UK Your research papers will be:

- available free of charge to the entire biomedical community

- peer reviewed and published immediately upon acceptance

- cited in PubMed and archived on PubMed Central

- yours - you keep the copyright 